(3) Babies who are receiving intravenous glucose and electrolyte solutions

(4) Babies who are being tube fed

(5) Babies who have had minor surgery in the previous 24 hours

(6) Babies with a tracheostomy

(7) Dying babies

(8) Babies who are being barrier nursed

(9) Babies who are receiving phototherapy

(10) Babies who are receiving special monitoring (for example, frequent glucose or bilirubin estimations)

(11) Other babies receiving constant supervision (for example, babies whose mothers are drug addicts)

(12) Babies receiving antibiotics

(13) Babies with conditions requiring radiological examination or other methods of imaging.

1 Royal College of Physicians of London. Medical care of the newborn in England and Wales. London: Royal College of Physicians of London, 1988.

2 Anonymous. Medical care of newborn babies [Editorial]. Lancet 1988:ii: 1344-6.

3 Department of Health and Social Security Expert Group on Special Care for
Babies. Report. London: DHSS, 1971. Chairman Sir Wilfrid Sheldon.) Report on Public Health and Medical Subjects, No 127

4 British Paediatric Association and Royal College of Obstetricians and (jynaecologists Liaison Committee. Recommendations for the improvement of infant care during the perinatal period in the l'nited Kingdom. A discussion document. London: British Paediatric Association and Royal College of Obstetricians and Gynaecologists, 1977

5 British Association of Perinatal Medicine Working Group. Referrals for neonatal medical care in the United Kingdom over one year. Br Med 7 1989;298: 169-72.

6 British Paediatric Association and British Association for Perinatal Paediatrics. Calegories of babies requiring neonatal care. London: British Paediatric Association and British Association for Perinatal Paediatrics, 1984.

7 McCullagh P, Nelder J. Models for data with a constant coefficient of variation. In: Generalised linear models. London: Chapman and Hall, variation. In:

8 Payne CD. The generalised linear interactive modelling system. Oxford: Numerical Algorithms Group, 1985

9 Simpson H, Walker G. Estimating the cots required for neonatal intensive care. Arch Dis Child 1981;56:90-3.

10 South East Thames Regional Perinatal Monitoring Group. Neonutal intensive care services. A draft strategy 1985-1995. London: South East Thames Regional Health Authority, 1987

11 Speidel B. Skimping on care of the newborn is false economy. Br Med $\mathcal{f}$ 1986;293:575

(Accepted 5 October 1989)

\title{
Needle aspiration of amoebic liver abscess
}

\author{
M P Sharma, R R Rai, S K Acharya, J C Samant Ray, B N Tandon
}

\section{Abstract}

Objective-To determine the value of needle aspiration in uncomplicated amoebic liver abscess.

Design-Randomised case-control study with a minimum follow up of one year, comparing patients treated with drugs alone with those treated with additional needle aspiration.

Setting-Referral based gastroenterology clinic.

Patients - 39 Consecutive patients with amoebic liver abscess in the right lobe, of whom 37 completed the study.

Intervention-Metronidazole $2.4 \mathrm{~g} /$ day was given to all patients for $\mathbf{1 0}$ days. Needle aspiration of the abscess was performed in 19 patients on the day of admission to hospital.

Main outcome measures-Abdominal pain, fever, anorexia, and hepatomegaly were measured. Erythrocyte sedimentation rate, serum aspartate, and alanine aminotransferase activities, and alkaline phosphatase activity were also measured.

Results-Clinical improvement was similar in both groups of patients. Improvement in haematological and biochemical variables and rates of healing of cavities were also similar.

Conclusions-Chemotherapy with potent tissue amoebicidal drugs such as metronidazole is optimally effective in treating amoebic liver abscess, and in uncomplicated cases routine aspiration is not required.

\section{Department of}

Gastroenterology and

Microbiology, All India

Institute of Medical

Sciences, New Delhi-

110029 , India

M P Sharma, DM, associate professor

R R Rai, DM, senior resident

S K Acharya, DM, assistant professor

J C Samant Ray, MD,

assistant professor

B N Tandon, MD, professor

Correspondence to:

Dr Sharma. nidazole treatment has also been reported, emphasising the importance of aspiration. ${ }^{3}$ Only few controlled trials of needle aspiration of amoebic liver abscess have been carried out. We compared the immediate and late effects of metronidazole treatment alone with a regimen comprising needle aspiration and metronidazole.

\section{Patients and methods}

Thirty nine patients with amoebic liver abscess diagnosed by using the standard accepted criteria ${ }^{4}$ entered the study. All patients had positive serological results for Entamoeba histolytica (1:400 or more by enzyme linked immunosorbent assay (ELISA) and indirect haemagglutination) and one or more lesions occupying space in the right lobe of the liver with characteristic features of amoebic liver abscess on ultrasound examination. ${ }^{5}$ Patients with an abscess in the left lobe, multiple liver abscesses, and impending rupture were excluded from the study. The patients were admitted to the Rajgarhia liver unit of this institute during January 1985 to October 1987 and were randomised to receive drug treatment alone (non-aspiration group) $(n=20)$ or drug treatment and aspiration $(n=19)$. All patients were treated with metronidazole $2.4 \mathrm{~g} /$ day in divided doses for 10 days. Aspiration of the abscess was carried out under aseptic conditions on the day of admission to hospital, and a mean of $682 \mathrm{ml}$ (range $210-1500 \mathrm{ml}$ ) pus was drained.

All patients were subjected to a thorough clinical examination. Four clinical variables-abdominal pain, fever, anorexia, and hepatomegaly - were assessed on the first, fourth, and 10th day. A reduction in pain by $75 \%$, improvement in appetite by $50 \%$, no fever for at least 72 hours, and regression of hepatomegaly by $30 \%$ or more were considered as definite criteria of improvement and successful treatment. Subsequently the patients were evaluated every three months for a minimum of 12 months. Haematological (erythrocyte sedimentation rate and total and differential counts) and biochemical studies (serum aspartate and alanine aminotransferase activities, and alkaline phosphatase activity) were carried out in all patients on the first, fourth, and 10th day. A raised erythrocyte sedimentation rate of $>30 \mathrm{~mm}$ in the first hour, total leucocyte count of $12.0 \times 10^{4} / 1$, serum alkaline phosphatase activity of 13 King-Armstrong units and aspartate aminotransferase activity $>40 \mathrm{U} / \mathrm{l}$ were considered 
abnormal. Success of treatment was marked by a normalisation of these variables. Ultrasound examination of the liver abscess was carried out on the first and 10th days. Subsequent examinations were repeated every three months for one year.

The $\chi^{2}$ test was used to compare quantitative variables. A Kaplan-Meier analysis was performed for the healing times, and the resulting curves were compared by using the log rank test.

\section{Results}

The two treatment groups were similar in the age, sex, and clinical distribution of patients on entry into the trial (table I). Thirty seven of the 39 patients were followed up for a year. Two patients in the group allocated to receive aspiration were lost to follow up seven days after entry into the trial and hence were not included in the final analysis. The mean size of the abscess cavity, however, was larger in the non-aspirated group than in the aspirated group (table I).

Ten days after starting treatment clinical improvement in abdominal pain, fever, and anorexia were similar in both groups, but there was no noticeable reduction in size of livers in either group, and the mean size remained the same as at the time of admission (table II). None of the patients required an operation, and all were free of symptoms three weeks after starting treatment.

Improvement in laboratory variables was also similar in both groups. On ultrasound examination at the end of 10 days of treatment the mean diameter of the abscess cavity remained almost the same as before treatment in both groups. Kaplan-Meier analysis of the

TABLE I-Clinical and biochemical variables of patients with amoebic liver abscess at admission

\begin{tabular}{lcc}
\hline & $\begin{array}{c}\text { Patients allocated to } \\
\text { aspiration and drug } \\
\text { treatment } \\
(\mathbf{n}=17)\end{array}$ & $\begin{array}{c}\text { Patients allocated to } \\
\text { drug treatment alone } \\
(\mathbf{n}=20)\end{array}$ \\
\hline Mean (SD) age (years) & $39 \cdot 5(10 \cdot 2)$ & $41(9 \cdot 8)$ \\
Men & 16 & 18 \\
Women & 1 & 2 \\
Abdominal pain & 17 & 18 \\
Fever & 17 & 19 \\
Anorexia & 16 & 18 \\
Hepatomegaly & 17 & 20 \\
Tenderness & 17 & 20 \\
Mean (SD) span of liver (cm) & $16(3 \cdot 2)$ & $17(2 \cdot 8)$ \\
Mean (SD) size of liver abscess & $54(22)$ & $72(20)$ \\
$\quad$ on ultrasonography (mm) & 54 & \\
\hline
\end{tabular}

${ }^{\star}$ Difference between groups significant $\mathrm{p}<0 \cdot 05$.

TABLE II-Comparison of clinical features considered to be evidence of improvement in patients with amoebic liver abscess. Figures are numbers of patients

\begin{tabular}{|c|c|c|}
\hline Clinical criteria & $\begin{array}{l}\text { Patients allocated to } \\
\text { aspiration and drug } \\
\text { treatment } \\
(n=17)\end{array}$ & $\begin{array}{l}\text { Patients allocated to } \\
\text { drug treatment alone } \\
\qquad(\mathrm{n}=20)\end{array}$ \\
\hline \multicolumn{3}{|l|}{ Pain: } \\
\hline On admission & 17 & 18 \\
\hline On 10th day & 7 & 6 \\
\hline \multicolumn{3}{|l|}{ Fever: } \\
\hline On admission & 17 & 19 \\
\hline On 10th day & 1 & 3 \\
\hline \multicolumn{3}{|l|}{ Anorexia: } \\
\hline On admission & 16 & 18 \\
\hline On 10th day & 6 & 8 \\
\hline \multicolumn{3}{|l|}{ Hepatomegaly: } \\
\hline On admission & 17 & 20 \\
\hline On 10th day & 17 & 20 \\
\hline
\end{tabular}

median healing time and median time for partial healing were similar in the two groups. There was also no difference in the rate of decrease of the size of the abscess at the end of one year (table III). No symptoms recurred in any patient during the one year of follow up.

TABLE III - Resolution of abscess cavity at one year

\begin{tabular}{lcc}
\hline & $\begin{array}{c}\text { Patients allocated to } \\
\text { aspiration and drug } \\
\text { treatment } \\
(\mathrm{n}=17)\end{array}$ & $\begin{array}{c}\text { Patients allocated to } \\
\text { drug treatment alone } \\
(\mathrm{n}=20)\end{array}$ \\
\hline $\begin{array}{l}\text { Complete resolution } \\
\text { More than 50\% resolution }\end{array}$ & 5 & 6 \\
$\begin{array}{l}\text { Less than 50\% resolution } \\
\text { Mean (SD) diameter of abscess } \\
\text { cavity }(\mathrm{mm}) \text { at end of year }\end{array}$ & 2 & 10 \\
\hline
\end{tabular}

\section{Discussion}

Our study showed that chemotherapy alone is as effective as routine needle aspiration combined with chemotherapy in the treatment of patients with amoebic liver abscess. The relief of symptoms and the improvement in biochemical variables in both groups at the end of 10 days of treatment were similar. No difference was found in the resolution of the abscess cavity at the end of 10 days and during the follow up of one year. There are few reports on the role of routine aspiration in patients with amoebic liver abscess. ${ }^{167}$ Our results agree with those of other studies. In the previous studies the patients were not followed up and the size of the abscess cavity was not assessed while the efficacy of the therapeutic methods was evaluated.

The lack of any difference in healing or recurrence of the abscess between the two groups in our study further strengthens the argument that routine aspiration is not needed in patients with amoebic liver abscess except in certain special cases such as patients with abscesses of the left lobe and impending rupture of the cavity. ${ }^{189}$ Even though the patients who received only chemotherapy had considerably larger cavities than the patients in the aspiration group, healing of the cavity in both groups remained the same at the end of one year. The number of patients with complete healing and more than $50 \%$ healing were also similar in the two groups at the end of one year. In the remaining patients the mean diameter of the residual cavity was similar in the two groups, implying that the size of the cavity does not influence the therapeutic response of the patients or the selection of the method of treatment.

1 Thompson JE, Forlenza S, Verma R. Amebic liver abscess: a therapeutic approach. Rev Infect Dis 1985; 7:171-9.

2 Peters RS, Gitlin N, Libke RD. Amebic liver abscess. Annual Review of Medicine 1981;32:161-74.

3 Krogstad DJ, Spencers JC, Healy DR. Current concepts in parasitology: amebiasis. $N$ Engl f Med 1978;298:262-5.

4 World Health Organisation Expert Committee. Amoebiasis. WHO Tech Rep Ser 1969;42:1-52.

5 Berry $M$, Bazaz $R$, Bhargava S. Amebic liver abscess sonographic diagnosis and management. Fournal of Clinical Ultrasound 1986;14:239-42.

6 Verlenden WL, Frey CF. Management of liver abscess. Am f Surg 1980;140: 53-9.

7 Braun B, Perrice H, Herzog P, Bomer N, Dormeyer HH. Diagnosis and therapy of liver abscess by ultrasonographic imaging, puncture and drainage. Hepatogastroenterology 1983;30:9-11.

8 Abuabara SF, Barrett JA, Hau T, Jonassan O. Amebic liver abscess. Arch Surg 1983;117:239-44.

9 Peters RS, Gilten N, Lebke RD. Amebic liver abscess. Annual Review of Medicine 1981;32:169-74.

(Accepted 12 September 1989) 